\title{
Entrepreneurship, Regional Development and Job Creation: the Case of Portugal
}

\author{
Rui Baptista \\ Centre for Innovation, Technology and Policy Research, IN+, Instituto Superior \\ Técnico, Technical University of Lisbon \\ Vítor Escária \\ CIRIUS, Instituto Superior de Economia e Gestão, Technical University of Lisbon \\ Paulo Madruga \\ CIRIUS, Instituto Superior de Economia e Gestão, Technical University of Lisbon
}

\begin{abstract}
This paper investigates whether a high level of new business formation in a region stimulates employment growth in that region. We look at the lag structure of these effects using a data set covering a fairly large time span (1982-2002). We find that indirect effects of new firm births on subsequent employment growth are stronger than direct effects. However, indirect effects only occur about eight years after new firm formation. In particular, and unlike the findings from studies of other countries using a similar approach, positive indirect effects do not seem to tail off in the Portuguese case. This is likely due to a general pattern of results in which lags appear to be longer for Portugal. In view of these results, we suggest that the lag times and magnitudes the effects on new firm formation on subsequent employment growth are likely dependent on the types and qualities of start-ups.
\end{abstract}

Acknowledgements: the authors would like to thank David Audretsch, Michael Fritsch, Pamela Mueller, André van Stel, David Storey, A. Roy Thurik, and participants at the 2005 IECER Conference at the University of Amsterdam, as well as at the Workshop on Long Term Effects of New Business Formation at the Max Planck Institute of Economics, Jena, July 2005. Rui Baptista gratefully acknowledges support from Portuguese Foundation for Science and Technology (FCT).

Corresponding Author: Rui Baptista, Centre for Innovation, Technology and Policy Research, IN+, Instituto Superior Técnico, Av. Rovisco Pais, 1049-001 Lisboa, Portugal.

Ph: +351.218.417.379. Fax: +351.218.496.156. E-mail: rui.baptista@ist.utl.pt. 


\section{Introduction}

In recent years, the relationship between new firm formation, business ownership (or self-employment) and economic progress has received considerable attention from scientists and policy makers. Europe and other industrialized regions of the globe have experienced considerable industrial re-structuring in the last three decades, switching from traditional manufacturing industries towards new and more complex technologies such as electronics, software and biotechnology. In this context, entrepreneurship and small firms play a particularly important role for two main reasons:

i. the use of new technologies has reduced the importance of scale economies in many sectors (Piore and Sabel, 1984; and Carlsson, 1989);

ii. the increasing pace of innovation and the shortening of product and technology life cycles seem to favour new entrants and small firms, which have greater flexibility to deal with radical change than large corporations (Christensen and Rosenbloom, 1995).

Under such circumstances, it would be expected that high levels of new firm formation should stimulate economic development and employment growth. Audretsch and Thurik $(2000,2001)$ argue that the role played by new firms in technological development has been enhanced by an increasing degree of uncertainty in the world economy, creating more room for innovative entry. Audretsch and Fritsch (2002) argue that high levels of new firm formation should have a stronger impact on employment in the regions where such formation has occurred.

The present paper examines whether there is a positive relationship between increases in new firm start-up rates and subsequent employment growth at the regional level. Results from recent research (Audretsch and Fritsch, 2002; Van Stel and Storey, 2004; Fritsch and Mueller, 2004) suggest that the hitherto ambiguous evidence on the relationship between new firm formation and both economic growth and net employment change - reported by, among others, Storey (1991) and Fritsch (1996) may be due to the long time lags required for positive effects of new entry to occur. Following Fritsch and Mueller (2004), this paper investigates whether there are significant time lags for the effects of new firm entry on employment in Portuguese regions, and examines the structure and extent of such lags. 
Section 2 of the paper outlines the theoretical background and empirical evidence with regard to two main propositions:

i. increases in new firm formation rates have a positive effect on employment growth;

ii. the effects of new firm formation on employment are stronger within the regions where such new firm formation has occurred.

Section 3 of the paper discusses data and measurement issues, and lays out the empirical approach used to examine the structure of lag effects of new firm formation on regional employment. Section 4 reports the results, while Section 5 presents some concluding remarks.

\section{Effects of New Firm Formation Employment Growth}

\subsection{Theoretical Background}

The first contribution of new firm formation to employment growth is, naturally, the number of jobs directly created by the successful new firms as they enter the market and grow. Comprehensive studies relating firm size to firm growth have produced what Geroski (1995) terms the stylized fact that (successful) smaller firms have higher growth rates than their larger counterparts. A central finding of this literature is that firm growth is negatively related to firm size and age. These conclusions are shared by most subsequent studies, despite differences in country, industry, time period, and methodology used (see Audretsch et al., 2004 for a review). More specifically, the evidence strongly supports the conclusion that the very young and very small firms tend to outperform their older and larger counterparts in terms of employment formation, even when corrected for the higher probabilities of exit.

However, net job formation by new firms might not be positive. As Van Stel and Storey (2004) point out, new firms only directly contribute a very small proportion of the stock of jobs in the economy and most new firms merely displace existing firms. Moreover, new businesses have a greater probability of failure than old businesses. According to Geroski (1995), the survival probability of most entrants is low and even successful entrants may take more than a decade to achieve a size comparable to the average incumbent. Moreover, the displacement of incumbents by successful entrants 
leads to declining market shares and, generally, to exit of these incumbents, with an ensuing reduction of the stock of jobs in the economy.

The net effect of new entry in terms of employment generation depends on whether new entrants bring about market growth. If new entry processes result only in selection mechanisms working through increased competition and "survival of the fittest" while the overall market volume remains constant, then the net effect of entry is unlikely to be significantly positive. Unless new firm entry generates significant positive indirect supply-side effects (spillovers), it is unlikely that higher rates of new business formation will lead to significant employment growth. Fritsch and Mueller (2004) provide a survey of such effects, which include: greater efficiency due to increased competition; greater productivity due to faster structural change; increased innovation; and greater product variety and quality brought about by new entrants.

It can be argued that the magnitude of positive supply-side spillovers from new firm entry depends on the "quality" of new entrants with regard to innovation, efficiency, quality and product differentiation. New firms provide a vehicle for the introduction of new ideas and innovation to an economy, which is a key source for long term economic growth (Romer 1986). Even though, as pointed out by Van Stel and Storey (2004), innovation in new firms seems to be not as frequent as expected, it is one of the main conduits through which new firm formation may impart positive supply-side spillovers on the economy.

Feldman (1994) argues that spillovers associated with innovation are stronger within relatively restricted geographical regions due to agglomeration externalities that increase the capacity of firms to tap into the local pool of new ideas, while Jaffe, Henderson and Trajtenberg (1993) provide evidence of geographical concentration of spillovers on innovative (patenting) activity. It is then possible to claim that any positive spillovers generated by new firm entry should occur primarily within the region where such entry occurred, thus making the regional effects of new firm entry particularly worthy of appraisal.

\subsection{Empirical Evidence}

Studies of the relationship between new firm formation and job creation exhibit very diverse results, frequently because of the variety of empirical approaches used. 
Johnson and Parker (1996) find evidence that growth in firm births and reduction in firm deaths significantly lowers unemployment. Ashcroft and Love (1996) find new firm formation to be strongly and positively associated with net employment change in Great Britain. Aghion et al. (2004) focus on the effect of entry on productivity growth, showing that more entry by foreign firms has led to faster total factor productivity growth in British manufacturing establishments during the period 198093.

At the regional level, evidence in favour of a significant positive impact of new firm formation on employment is provided by Reynolds (1994, 1999), and Acs and Armington (2004). However, the magnitude of such relationship seems to vary over time. Foelster (2000) finds a positive effect of increased self-employment rates on regional employment for Sweden. Similar evidence is provided by Brixy and Grotz (2004) for Germany.

Other studies of the effect of new firm formation on employment provide less clear evidence. Fritsch (1996) finds a positive statistical relationship between entry rates and employment change for manufacturing in Germany, but a negative relationship for the service sector and the whole economy. Audretsch and Fritsch (2002) find that regions with high start-up rates in the 1980s had high employment growth in the 1990s. This result leads the authors to suggest that the lack of clarity with regard to the impacts of new firm formation on employment growth may be attributed to the relatively long time lags that are required for these impacts to become visible. Audretsch et al. (2005) estimate a model of mutual, intertemporal relationships between changes in self-employment and in unemployment rates for 23 OECD countries finding overall positive effects that, however, do not hold for all the countries in the sample - such is the case of Portugal, as reported by Baptista, Van Stel and Thurik (2006).

Van Stel and Storey (2004) investigate the relevance of time lags in the effect of new firm births on employment for the regions of Great Britain, finding that rates of growth of regional employment are positively shaped by entry occurring in earlier years. Fritsch and Mueller (2004) model the lag structure of the effects of new firm entry on regional employment, finding that net employment effects of new firm formation are small in the year of entry and become negative over the first six years. 
Positive effects only occur after that, peaking around the eighth year and fading away after the tenth year.

\section{Data and Empirical Methodology}

\subsection{Data and Measurement Issues}

Data on regional entry and employment come from "Quadros de Pessoal," a longitudinal matched employer-employee microdata set based on information gathered by an annual survey conducted by the Portuguese Ministry of Labour and Social Solidarity covering all business units with at least one wage-earner in the Portuguese economy for 1982 to 2002 inclusive. $^{1}$ We worked with the original raw data which include over 100,000 firms in each year, so we were able to compute entry rates ourselves. The main strength of the data set is probably the amount of information it reports and the number of units considered in the analysis as it covers most of the private sector of the economy.

The specific form in which the data set was built enables us to distinguish between entry and birth of the business units, which is very important to separate true start-ups from other processes. New firm formation is then measured by yearly regional startup rates. ${ }^{2}$ Start-ups in the agricultural sector are excluded.

Following Fritsch and Mueller (2004), we used as indicator of regional development the relative change over a two-year period of employment in the private sector, in order to avoid disturbances due to short-run fluctuations. In order to control for differences in the size of regions, entry rates are measured relative to regional dimension. Following Ashcroft, Love and Malloy (1991), the regional size denominator controls for different absolute sizes of regions. Following Garofoli (1994), Audretsch and Fritsch (1994), and Fritsch and Mueller (2004), regional startup rates are measured using the size of the regional workforce as denominator ("labour market” approach). Garofoli (1994) argues that this approach has advantages

\footnotetext{
${ }^{1}$ The database is property of the Portuguese government and can be accessed on-site at the Observatory of the Ministry of Labour and Social Solidarity. The database is presented in more detail in Escária and Madruga (2002).

${ }^{2}$ Start-ups do include new branch plants by existing firms, so all new establishments are included. NACE A and NACE B (agriculture, hunting and forestry; and fisheries) are excluded - so we have all new establishments in manufacturing and services.
} 
over the use of the total number of firms in a region as the denominator ("business stock" approach) as the latter is misleading in regions with a few large firms - in such case, small numbers of new firms would provide an artificially high birth rate, primarily because of the small denominator.

The relative importance of incumbents and start-ups varies systematically across both regions and industries. For example, start-up rates are systematically higher in services than in manufacturing. Entrepreneurial activity could be systematically overestimated in regions with a high share of industries where start-ups play an important role, while the role of new firm formation in regions with a high share of industries where start-ups are relatively few would be underestimated. To account for differences in industrial structures and in the relative importance of start-ups and incumbents across industries, a shift-share procedure (Ashcroft, Love and Malloy, 1991; Audretsch and Fritsch, 2002) is applied in order to derive a measure of sectoradjusted start-up activity. The shift-share measure adjusts the raw data by imposing the same industry composition in each region. Thus, the sector-adjusted number of start-ups is defined as the number of new firms in a region that can be expected to be observed if the composition of industries was identical across all regions. Industry structure is measured on the basis of the numbers of establishments per industry. In a first step, we calculate for each region $i$ the hypothetical number of establishments $h n e_{i j}$ in industry $j$ :

$$
\text { hne }_{i j}=E_{i} * S_{j} \text { with } \quad E_{i}=\sum_{j} e_{i j} \text { and } \quad S_{j}=\frac{E_{j}}{E}=\frac{\sum_{j} e_{i j}}{\sum_{i j} e_{i j}}
$$

where: $e_{i j}$ - observed number of establishments of industry $j$ in region $I ; E_{i}$ - overall number of establishments in region $I ; S_{j}$ - share of establishments of industry $j$ with regard to total number of private establishments in the country. The hypothetical number of start-ups in region $i$ can be calculated by the number of establishments of each industry in the region $\left(h n e_{i j}\right)$ with the start-up rate of the respective industry in the country as a whole $S_{t} R_{j}$. This leads to: 
$H N S t_{i}=\sum_{j} h n e_{i j} * S t R_{j}=\sum_{j} B_{i} * S t R_{j}$

with $\quad S t R j=\frac{S t_{j}}{E_{j}}=\frac{\sum_{i} s t_{i j}}{\sum_{i} e_{i j}}$

This hypothetical number of start-ups $\left(H N S t_{i}\right)$ is not influenced by deviations of the regional industry structure from the national average and other region specific factors. To estimate the impact of a deviation of a region's industry structure on the number of start-ups, we multiply the difference between the hypothetical and the observed number of establishments in each industry by the national start-up rate of the respective industry. Summing up the results over all industries, we obtain the number of start-ups induced by differences between the industry structure of the respective region and the national average $\left(H I S t_{i}\right)$.

$H I S t_{i}=\sum_{j}\left(e_{i j}-h n e_{i j}\right) * S t R_{j}$

Subtracting this number from the observed number of start-ups yields the sectoradjusted number of start-ups in the region. We can assume this number is independent of diverging industry structures in the regions. This adjustment means that any differences in the effects of new firm formation on employment growth across regions picked up by the analysis will not be associated with differences in regional industry structures.

The regional unit used in the present paper is the NUTS3 which, in the case of Portugal, yields 30 regions. These regional units are somewhat larger in size than the ones used by Fritsch and Mueller (2004) ${ }^{3}$. While the use of smaller spatial units would have the advantage of providing a higher number of cross-section observations in the panel, the fact that small counties may include only parts of larger urban agglomerations means that positive agglomeration externalities which prove to be relevant for larger regions than a county would not be picked up in the analysis. Although Portugal is a relatively small country when compared to Germany (or even West Germany), it has considerably large urban agglomerations, both in terms of land area and population, thus making the use of a relatively larger spatial unit advantageous.

\footnotetext{
${ }^{3}$ Fritsch and Mueller (2004) use data for 326 West German counties (kreise).
} 


\section{2. $\quad$ Empirical Approach}

The basic relationship to be modelled has the following form:

$\Delta E M P_{t}=\left[\alpha_{0} \cdot B I R_{t}+\alpha_{1} \cdot B I R_{t-1}+\ldots+\alpha_{n} \cdot B I R_{t-n}\right]+X_{t \cdot} \beta$

where: $\triangle E M P_{t}-$ change in regional employment between period $t-2$ and period $t$; $B I R_{t-i}-$ sector-adjusted firm birth rates $^{4}$ at start of period $t-i$, with $i=0, \ldots, n$ being the lag periods considered; and $X_{t}-$ control variables. We analyse the impact of new firm formation on regional employment growth using the yearly start-up rates at the beginning of the current employment change period and for the ten preceding years.

The estimation uses panel data regression techniques that allow us to account for unobserved region-specific factors. Application of the Huber/White/Sandwich procedure provides robust estimates of the standard errors. As an alternative method, panel data estimation of fixed effects was also conducted in order to check the robustness of the results. Regional fixed effects should play a significant role in determining regional employment change. Differences between regions may arise principally due to the following types of factors:

i. differences in regional industrial composition - different industries typically face different product life cycles and may face different overall business cycles - as specified in the previous sub-section, using sectoradjusted employment growth rates should eliminate this kind of regional fixed effect;

ii. differences in local labour market conditions, house prices and the extent of knowledge/innovation spillovers;

iii. different regional cultural attitudes towards entrepreneurship: regions may differ in how they favour entrepreneurial activity and how they react to business failure - this is dubbed the "Upas Tree" effect by Van Stel and Storey (2004), who argue that this effect typically interacts with public policy effects.

\footnotetext{
${ }^{4}$ Calculated from the sector-adjusted number of start-ups - see equation 3 - using the labour market approach.
} 
Estimation of region-specific fixed effects is expected to capture regional differences that are not corrected by the shift-share procedure described above. Additionally, a control variable is included in estimation. This variable is "economic size" of the region, measured as the product of population density and GDP per capita, i.e. income per square kilometre. The use of this variable aims to capture any agglomeration externalities arising from regional size, taken as a combination of density and wealth. ${ }^{5}$ Time dummies are used to account for the business cycle and other macroeconomic factors affecting all regions in the same way. ${ }^{6}$

Model estimations also correct for spatial autocorrelation. Following Anselin (1988), and Anselin and Florax (1995), the average of the residuals in adjacent regions is included in the estimation. These residuals provide an indication of unobserved influences that affect larger geographical entities than NUTS3 and that are not entirely reflected in the explanatory variables.

Correlations between start-up rates of successive years are presented in Table 1. Correlations between start-up rates are mostly significant, although not as strong as those reported by Fritsch and Mueller (2004). Such correlation leads to multicollinearity that makes interpretation of coefficients in the models difficult. In order to deal with this problem, the lag structures for the effect of regional start-up rates on regional employment growth are estimated using Almon polynomials (see Trivedi, 1978; and Van Stel and Storey, 2004, for details). The Almon lag procedure reduces the effects of multicollinearity in distributed lag settings by imposing a particular structure on the lag coefficients. In the Almon method, parameter restrictions are imposed in such away that the coefficients of the lagged variables are a polynomial function of the lag. In this way, the start-up rate coefficients are reparameterized "smoothly."

\footnotetext{
${ }^{5}$ The control variable was found not to be statistically significant in most regressions Estimations were also carried out using each of the two variables - population density and per capita GDP - separately, reaching similar results.

${ }^{6}$ Coefficients for time dummies were mostly significant. Results are not reported here but are available from the authors upon request.
} 


\section{4. $\quad$ Results}

Table 2 presents the results for both the unrestricted panel data model and the Almon lag polynomial procedure, using the Huber-White-Sandwich estimation procedure. ${ }^{7}$ Results are presented for the effects on employment change of business formation rates for the current period and up to period $t-10$.

Estimation of the Almon polynomial lag model assumes that the effect of changes in yearly start-up rates is distributed over eleven periods. Almon lag models were estimated for the second through to the sixth orders. A critical issue in applying the Almon lag procedure is determining which order of polynomial to consider. An appropriate way to do this is to use Likelihood Ratio tests. Comparing a $\mathrm{N}^{\text {th }}$ order Almon polynomial model with a $(\mathrm{N}+1)^{\text {th }}$ order Almon polynomial model comes down to a Likelihood Ratio test with one restriction, since each additional order of the polynomial adds one restriction to the model. In the present case, we find that the $5^{\text {th }}$ order polynomial appears to provide the best fit for the lag structure of the effects of new firm formation on regional employment change, so we present the estimation results for that model in Table $2 .{ }^{8}$

Figure 1 presents the lag structure of the effects of new firm formation rates on employment growth for the $5^{\text {th }}$ order polynomial estimation. ${ }^{9}$ New firm formation has a relatively low positive impact on employment growth for the start-up year and the three years after that, possibly reflecting the small average size of start-ups, as well as high mortality rates. Studies of the evolution of new businesses, such as Boeri and Cramer (1992) for Germany, and Mata, Portugal and Guimarães (1995) for Portugal, find that employment in entry cohorts tends to stagnate or even decline from the second or the third year onwards, thus corroborating the decline in the positive effect of new business formation on employment registered in the present study.

The impact of new firm formation on employment change becomes negative in the fourth year after start-up. Low negative impacts dominate until the eighth year after start-up. These negative impacts are likely to reflect market selection spurred on by new entrants, leading to displacement of incumbents. We find that the duration of this

\footnotetext{
${ }^{7}$ Huber-White-Sandwich robust estimation takes into account variations in employment growth within and between regions over time simultaneously, being therefore preferable to fixed effects estimation.

${ }^{8}$ Results for other lag structures are available from the authors upon request.

${ }^{9}$ The lag structures for lower order polynomials are all approximately u-shaped.
} 
period of negative effects is larger for Portugal than for West Germany where, according to Fritsch and Mueller (2004), effects of new business formation on employment growth become positive again from about the sixth year after start-up. Compared with the case of Germany, as well as with that of Great Britain (as reported in the present volume by Mueller, Van Stel and Storey, 2007), the magnitude of these effects is relatively low.

From the eighth year after start-up onwards, a growing positive effect of new entry on employment change is observed. This effect does not tail off within the period under scrutiny, suggesting that a longer time span of analysis is required to assess the effects of new firm formation on subsequent employment growth in their entirety. The overall effect seems to be clearly positive, nonetheless.

Unlike the cases of Germany (Fritsch and Mueller, 2004) and Great Britain (Mueller, Van Stel and Storey, 2007), where indirect positive effects of new firm formation occur earlier and then fade away again after the ninth or tenth year, these positive effects show no sign of receding. While it seems clear that market selection (or displacement) effects originating from new entry are weaker in magnitude than in Germany and Great Britain, they seem to last longer, and therefore positive indirect effects arise later (eight year after start-up) in the Portuguese case than in the German (sixth year after start-up) or British (four years after start-up cases). This suggests that a larger time span of analysis is needed to determine whether positive indirect effects do indeed fade away, although it seems logical that this should happen. Given the present time span of analysis, one can only speculate that the lag structure of the effects of new business start-ups on employment growth should eventually assume a similar shape to those reported by Fritsch and Mueller (2004) for West Germany, and Mueller, Van Stel and Storey (2007) for Great Britain.

The reasons for this longer time lag (and smaller magnitude) associated with the market selection, or displacement effect might be linked with greater structural rigidity of product and factor markets in Portugal, when compared with Great Britain and West Germany. Moreover, since studies control for differences in regional industrial structures, differences across countries in the magnitudes and time lags of effects of new business formation on employment change are likely to be due to the specific characteristics of start-ups. It can be argued that the magnitude of positive supply-side spillovers from new firm entry depends on the "quality" of new entrants 
with regard to innovation, efficiency, quality and product differentiation. It may just be the case that, on average, Portuguese start-ups display less innovative, markettransforming qualities than their German or British counterparts, therefore leading to smaller displacement effects on incumbents, and taking longer to induce indirect, supply-side effects that lead to employment growth. Nevertheless, these positive effects on employment do eventually occur.

\section{Concluding Remarks}

The present paper has looked at the effect of new business formation in a region on employment growth in that region. The study investigates the lag structure of these effects, using a data set for the Portuguese economy covering a fairly large time span (1982-2002). The indirect supply-side effects of new firm births, whether due to greater competition, efficiency or innovation, are considerably stronger than the direct effects associated with employment creation by the new entrants. However, such supply-side effects occur only after a time lag of eight years, leading to a pattern of lagged effects that is, in some way, "delayed" when compared with that registered in other countries (e.g. Germany and Great Britain).

This "delay" is associated in particular with a longer period during which weak negative effects of new firm formation on employment change dominate. While market selection, or displacement, takes longer to occur, probably due to structural rigidities in labor and product markets, the negative effects it spurs on employment are also of less magnitude than in other countries, possibly due to the same rigidities, which prevent market re-structuring from occurring.

Since the analysis conducted in the present paper follows other studies (e.g. Fritsch and Mueller, 2004; Mueller, Van Stel and Storey, 2007) in correcting for differences in the industry structure of regions, it can also be suggested that differences in start-up "quality" may explain differences across regions and countries in the size and structure of lagged effects: the size of positive effects and the lag time for those effects to ensue will vary according to the type of entrant, as not all entrants are equally efficient and/or innovative. In the Portuguese case, it is likely that the relatively high prevalence of subsistence, or necessity-based, entrepreneurial activity is associated with high mortality and low growth rates for new firms, thus leading to 
relatively small effects of new business formation on employment growth (Baptista, Van Stel and Thurik, 2006).

Further research should therefore focus on the effects of different types of entry considering, for example, initial size or the existence of foreign investment as factors differentiating between new entrants. Studies of new firm survival, such as the one by Mata, Portugal and Guimarães (1995), have found that initial size is a good indicator of the probability of survival, while several authors have argued that foreign direct investment is an important conduit for supply-side spillovers (see Blomström and Kokko, 1998 for a survey). In a related study, Baptista and Preto (2006) divide entry rates in the Portuguese economy into entry by large and small firms; foreign-owned and domestic-owned firms; and knowledge-based and other firms, finding that effects of new firm formation on subsequent employment change are different according to the type of entrant. Start-ups that are larger, foreign-owned and/or knowledge-based have considerably stronger effects on industrial re-structuring and employment change, whether due to market selection processes or supply-side spillovers.

Further research should also attempt to distinguish between the direct and indirect supply-side effects more accurately by analyzing the individual data. In particular, net employment growth in a region could be decomposed in (gross) employment increases and decreases due to entry and exit, and changes in employment originating from incumbent firms. Another possible avenue for research on the long term effects of new business formation is to focus on in-depth studies of the different effects of entry on market processes in different types of industries.

\section{Bibliographical References}

Acs, Zoltan and Catherine Armington, 2004, "Employment Growth and Entrepreneurial Activity in Cities," Discussion Paper on Entrepreneurship, Growth and Public Policy \#13/2004, Max Planck Institute for Research into Economic Systems, Jena.

Acs, Zoltan and David B. Audretsch, 1990, Innovation and Small Firms, Cambridge, Mass.: MIT Press.

Aghion, P., Blundell, R., Griffith, R., Howitt, P. and S. Prantl, 2004, "Entry and Productivity Growth: Evidence from Microlevel Panel Data," Journal of the European Economic Association, 2, 265-276.

Anselin, L.,1988, Spatial Econometrics: Methods and Models, Dordrecht: Kluwer. 
Anselin, L. and R. Florax, 1995, "New Directions in Spatial Econometrics: Introduction," in Anselin, L. and R. Florax, (Eds.) New Directions in Spatial Econometrics, Berlin: Springer.

Ashcroft, B. and J. Love, 1996, "Firm Births and Employment Change in the British Counties: 1981-89," Papers in Regional Science, 75, 483-500.

Ashcroft, B., J. Love, J. and E. Malloy, 1991, "New Firm Formation in the British Counties with Special Reference to Scotland," Regional Studies, 25, 395-409.

Audretsch, David B. and Michael Fritsch, 1994, "On the Measurement of entry Rates," Empirica, 21, July, 105-113.

Audretsch, David B. and Michael Fritsch, 2002, "Growth Regimes over Time and Space," Regional Studies 36, 113-124.

Audretsch, David B. and A. Roy Thurik, 2000, "Capitalism and Democracy in the $21^{\text {st }}$ Century: from the Managed to the Entrepreneurial Economy," Journal of Evolutionary Economics, 10, 17-34.

Audretsch, David B. and A. Roy Thurik, 2001, "What is New about the New Economy: Sources of Growth in the Managed and Entrepreneurial Economies," Industrial and Corporate Change, 19, 795-821.

Audretsch, D.B., M.A. Carree, A.J. van Stel and A.R. Thurik, 2005, "Does SelfEmployment Reduce Unemployment?" Papers on Entrepreneurship, Growth and Public Policy \#07/2005. Max Planck Institute of Economics, Jena, Germany.

Audretsch, D.B., L. Klomp, E. Santarelli and A.R. Thurik, 2004, "Gibrat's Law: Are the Services Different?" Review of Industrial Organization, 24, 321-324.

Baptista, Rui and Miguel T. Preto, 2006, "Entrepreneurship And Industrial ReStructuring: What Kinds Of Start-Ups Matter Most For Job Creation?" Paper presented at the $3^{\text {rd }}$ Hellenic Workshop on Efficiency and Productivity, University of Patras, Greece, June.

Baptista, Rui, A.J. van Stel and A. Roy Thurik, 2006, "Entrepreneurship, Industrial Re-structuring and Unemployment in Portugal," in Entrepreneurship, Growth, and Innovation: the Dynamics of Firms and Industries. International Studies in Entrepreneurship, Enrico Santarelli (ed.), Springer Verlag.

Blomström, M. and A. Kokko, 1998, "Multinational Corporations and Spillovers," Journal of Economic Surveys, 12, 1-31.

Boeri, T. and U. Cramer, 1992, "Employment Growth, Incumbents and Entrants Evidence from Germany," International Journal of Industrial Organization 10, 545565 .

Brixy U. and R. Grotz, 2004, "Entry Rates, the Share of Surviving Businesses and Employment Growth: Differences of the Economic Performance of Newly Founded Firms in West and East Germany," in Dowling, M., Schmude, J. and D. KnyphausenAufsess (Eds.), Advances in Interdisciplinary European Entrepreneurship Research, Muenster: Lit.

Carlsson, Bo, 1989, "The Evolution of Manufacturing Technology and its Impact on Industrial Structure: an International Study, Small Business Economics, 1(1), 21-37. 
Christensen, C. and J. Rosenbloom., 1995, "Explaining the attacker's advantage: technological paradigms, organizational dynamics and the value network," Research Policy, 24, 233-257.

Escária, V. and P. Madruga, 2002, "The Construction of a Longitudinal Matched Employer-Employee Microdata Data Set," Mimeo, CIRIUS, ISEG, Technical University of Lisbon.

Feldman, M.P., 1994, The Geography of Innovation, Dordrecht: Kluwer Academic Publishers.

Foelster, S., 2000, “Do Entrepreneurs Create Jobs?” Small Business Economics 14, 137-148.

Fritsch M., 1996, Turbulence and Growth in West Germany: a Comparison of Evidence by Regions and Industries, Review of Industrial Organization, 11, 231-251.

Fritsch, M. and P. Mueller, 2004, "The Effects of New Business Formation on Regional Development over Time," Regional Studies, 38, 961-975.

Garofoli, G., 1994, "New Firm Formation and Regional Development: the Case of Italy," Regional Studies, 28, 381-393.

Geroski, Paul A., 1995, “What Do We Know About Entry?” International Journal of Industrial Organization, 13, 421- 440.

Jaffe, A., M. Trajtenberg and R. Henderson, 1993, "Geographic Localization of Knowledge Spillovers as Evidenced by Patent Citations," Quarterly Journal of Economics, 108, 577-598.

Johnson, P. and S. Parker, 1996, "Spatial Variations in the Determinants and Effects of Firm Births and Deaths. Regional Studies, 30, 679-688.

Mata, José, P. Portugal and P. Guimarães, 1995, "The Survival of New Plants: Startup Conditions and Post-entry Evolution," International Journal of Industrial Organization, 13, 459-481.

Mueller, Pamela, A.J. van Stel and D.J Storey, 2007, "The effects of new firm formation on regional development over time: The case of Great Britain," Small Business Economics, present issue.

Piore, Michael and C. Sabel, 1984, The Second Industrial Divide: Possibilities for Prosperity, New York: Basic Books.

Reynolds, Paul D., 1994, "Autonomous Firm Dynamics and Economic Growth in the United States, 1986-90," Regional Studies, 27, 429-442.

Reynolds, Paul D., 1999, "Creative Destruction: Source or Symptom of Economic Growth?" in Z. Acs, B. Carlsson. and C. Karlsson (Eds.), Entrepreneurship, Small and Medium-sized Enterprises and the Macroeconomy, Cambridge: Cambridge University Press.

Romer, Paul, 1986, “Increasing Returns and Long-run Growth,” Journal of Political Economy, 94, 1002-1037

Schumpeter J. A., 1934, The Theory of Economic Development, Cambridge, MA: Cambridge University Press.

Stel, A.J. van and D.J. Storey, 2004, "The Link between Firm Births and Job Creation: Is there an Upas Tree Effect?" Regional Studies, 38, 893-909. 
Storey, David J., 1991, "The Birth of New Firms - Does Unemployment Matter? A Review of the Evidence," Small Business Economics, 3, 167-178.

Trivedi, Pravin K., 1978, "Estimation of a Distributed Lag Model under Quadratic Loss," Econometrica, 46(5), 1181-1183. 
Table 1: Correlation matrix of sector adjusted start-up rates for subsequent time periods (labour market approach)

\begin{tabular}{|l|r|r|r|r|r|r|r|r|r|r|r|}
\hline & Year t & $\begin{array}{r}\text { Year } \\
\mathrm{t}-1\end{array}$ & $\begin{array}{r}\text { Year } \\
\mathrm{t}-2\end{array}$ & $\begin{array}{r}\text { Year } \\
\mathrm{t}-3\end{array}$ & $\begin{array}{r}\text { Year } \\
\mathrm{t}-4\end{array}$ & $\begin{array}{r}\text { Year } \\
\mathrm{t}-5\end{array}$ & $\begin{array}{r}\text { Year } \\
\mathrm{t}-6\end{array}$ & $\begin{array}{r}\text { Year } \\
\mathrm{t}-7\end{array}$ & $\begin{array}{r}\text { Year } \\
\mathrm{t}-8\end{array}$ & $\begin{array}{r}\text { Year } \\
\mathrm{t}-9\end{array}$ & $\begin{array}{r}\text { Year } \\
\mathrm{t}-10\end{array}$ \\
\hline Year t & 1.000 & $0.474 *$ & $0.468 *$ & $0.510 *$ & $0.505 *$ & $0.529 * * 0.555$ & $0.499 *$ & $0.477 *$ & $0.499 *$ & $0.516 *$ \\
\hline Year t-1 & & 1.000 & $0.473 *$ & $0.461 *$ & $0.502 *$ & $0.514 *$ & $0.531 * * 0.532$ & $0.500 *$ & $0.486 *$ & $0.503 *$ \\
\hline Year t-2 & & & 1.000 & $0.469 *$ & $0.455^{*}$ & $0.497 *$ & $0.506 * * 0.531$ & $0.524 *$ & $0.495 *$ & $0.475 *$ \\
\hline Year t-3 & & & & 1.000 & $0.456 *$ & $0.453 *$ & $0.492 * * 0.494$ & $0.525 *$ & $0.515 *$ & $0.486 *$ \\
\hline Year t-4 & & & & 1.000 & $0.453 *$ & $0.445 * * 0.476$ & $0.481 *$ & $0.521 *$ & $0.505 *$ \\
\hline Year t-5 & & & & & & 1.000 & $0.445 * * 0.443$ & $0.469 *$ & $0.474 *$ & $0.514 *$ \\
\hline Year t-6 & & & & & & $1.000 * 0.435$ & $0.432 *$ & $0.462 *$ & $0.463 *$ \\
\hline Year t-7 & & & & & & & & 1.000 & $0.428 *$ & $0.428 *$ & $0.459 *$ \\
\hline Year t-8 & & & & & & & & & 1.000 & $0.419 *$ & $0.415 *$ \\
\hline Year t-9 & & & & & & & & & & 1.000 & $0.408 *$ \\
\hline Year t-10 & & & & & & & & & & & 1.000 \\
\hline
\end{tabular}

* statistically significant at 5\% level 
Table 2: The impact of new business formation on subsequent (sector adjusted) change in regional employment (robust Huber-White-Sandwich regression) ${ }^{10}$

\begin{tabular}{|c|c|c|c|c|}
\hline \multicolumn{5}{|c|}{ OLS estimator (Huber White) } \\
\hline \multirow[b]{2}{*}{ Start-up rate current year } & Unrestricted & \multicolumn{3}{|c|}{ Almon Lag (5th order polynomial) } \\
\hline & $\begin{array}{c}11.540 * \\
(2.28)\end{array}$ & $\alpha_{0}$ & $\begin{array}{l}0.433 \\
(1.22)\end{array}$ & 0.433 \\
\hline Start-up rate year t-1 & $\begin{array}{l}5.295 \\
(1.56)\end{array}$ & $\alpha_{1}$ & $\begin{array}{l}-0.179 * \\
(-1.75)\end{array}$ & 0.335 \\
\hline Start-up rate year $\mathrm{t}-2$ & $\begin{array}{l}-0.950 \\
(-0.21)\end{array}$ & $\alpha_{2}$ & $\begin{array}{l}0.095 \\
(1.54)\end{array}$ & 0.318 \\
\hline Start-up rate year $\mathrm{t}-3$ & $\begin{array}{l}-9.382 * \\
(-2.59)\end{array}$ & $\alpha_{3}$ & $\begin{array}{l}-0.010 \\
(-1.58)\end{array}$ & 0.237 \\
\hline Start-up rate year $\mathrm{t}-4$ & $\begin{array}{l}7.229 \\
(1.38)\end{array}$ & $\alpha_{4}$ & $\begin{array}{l}-0.005 \\
(-1.58)\end{array}$ & -0.024 \\
\hline Start-up rate year t-5 & $\begin{array}{l}-8.508 * \\
(-2.08)\end{array}$ & $\alpha_{5}$ & $\begin{array}{l}0.001 * \\
(1.74)\end{array}$ & -0.477 \\
\hline Start-up rate year t-6 & $\begin{array}{c}0.486 \\
(0.17)\end{array}$ & & & -0.962 \\
\hline Start-up rate year t-7 & $\begin{array}{l}-2.214 \\
(-0.65)\end{array}$ & & & -1.066 \\
\hline Start-up rate year t- 8 & $\begin{array}{l}-1.757 \\
(-0.99)\end{array}$ & & & -0.057 \\
\hline Start-up rate year t- 9 & $\begin{array}{l}2.169 \\
(1.44)\end{array}$ & & & 3.197 \\
\hline Start-up rate year $\mathrm{t}-10$ & $\begin{array}{l}9.295 * \\
(2.48)\end{array}$ & & & 10.294 \\
\hline Economic size & $\begin{array}{r}0.000 \\
(-0.48)\end{array}$ & & & $\begin{array}{r}0.000 \\
(-0.99)\end{array}$ \\
\hline Spatial Autocorrelation & $\begin{array}{l}0.419 * \\
(1.87)\end{array}$ & & & $\begin{array}{l}0.331 \\
(1.16)\end{array}$ \\
\hline Constant & $\begin{array}{l}-8.209 \\
(-1.44)\end{array}$ & & & $\begin{array}{r}-15.148 \\
(-0.70)\end{array}$ \\
\hline $\mathrm{R}^{2}$ & 0.238 & & & 0.226 \\
\hline Log-Likelihood & -1247.165 & & & -1249.197 \\
\hline F-value & 50.990 & & & 12.300 \\
\hline N. Observations & 270 & & & 270 \\
\hline
\end{tabular}

\footnotetext{
${ }^{10}$ Numbers in brackets are $\mathrm{t}$-values; * indicates the coefficient is statistically significant at the $5 \%$ confidence level.
} 
Figure 1: The lag structure of the impact of new business formation on subsequent (sector adjusted) change in regional employment (robust HuberWhite-Sandwich regression)

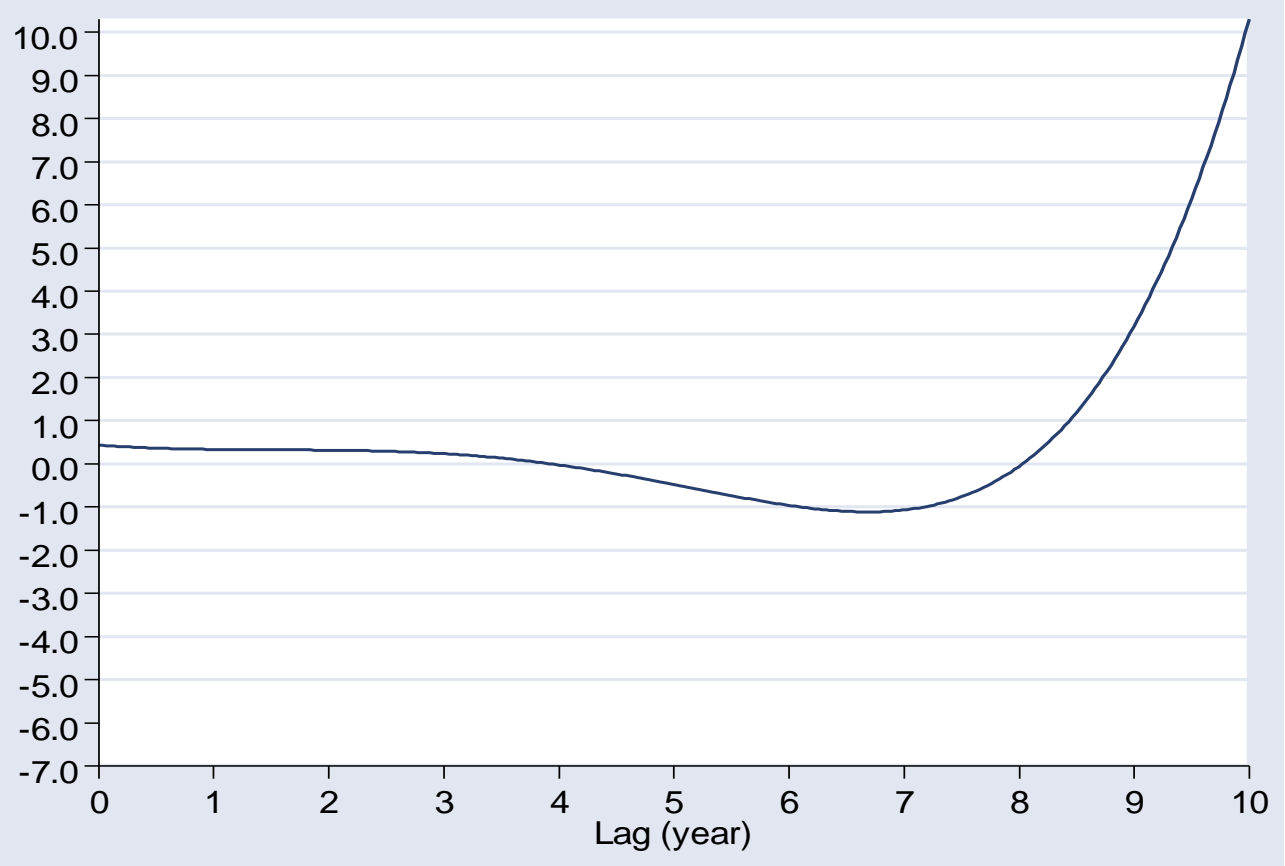

